\title{
Heat Exchanger Device
}

National Cancer Institute

\section{Source}

National Cancer Institute. Heat Exchanger Device. NCI Thesaurus. Code C49984.

A device designed to transfer heat between fluids across a barrier or to the environment. 